\title{
CORPORATE SOCIAL RESPONSIBILITY (CSR) AS CORPORATE GOVERNANCE MODEL FOR STATE OWNED ENTERPRISES (SOE)
}

\begin{abstract}
:
It is widely acknowledged that Corporate Social Responsibility is a modern trend among big corporations who are taking responsibility for supporting the environment and improving social wellbeing. Majority of the Big Corporations try to follow this trend and implement Corporate Social Responsibility (CSR) as a corporate governance and business model in their corporate structures and activities.
\end{abstract}

CSR underlines the social role of Corporations and promotes their involvement in improving the working conditions of employees, ensuring safety regulations and improving the environmental protection measures. At the same time, this corporate governance model does not discourage corporations from profitable economic conduct but advocates them to support the community with strengthening the vulnerable groups of society, supporting small businesses, providing trainings, coordinating activities with non-commercial entities, etc.

Although, if the CSR is a free choice generally for commercial entities, it becomes somehow "mandatory" for State Shareholding enterprises. These are enterprises where state is holding all or majority of shares. As these corporations are owned by the state, and therefore, indirectly by the society, corporate social responsibility should be a mandatory corporate governance model for such companies. This will enhance their role in serving public.

However, in many countries State Owned Enterprises (SOE) lack transparency and openness which affects their accountability level as well. With low level of transparency, it is difficult to define the social and environmental benefits implemented by the SOE.

The aim of this speech will be to highlight the importance of Corporate Social Responsibility for State Owned Enterprises. At the same time, the speech will provide new understanding of CSR, with characterizing CSR as a governance model which includes the transparency, openness and higher accountability of the corporations before community. Emphasizing, that state corporations should serve public not only in a social and environmentally safe way but also in a responsible, open and accountable manner.

This speech will be presented as part of the findings of the Scientific Project. This work was supported by Shota Rustaveli National Science Foundation (SRNSF) [Grant Number: \#217878; Project Title: Legal Regulation, Challenges and Recommendations for Effective Corporate Governance System in State Shareholding Enterprises]. The speech will be presented by the Head of the Project - Davit Maisuradze.

\section{Keywords:}


CSR, SOE, Accountability

JEL Classification: G38, K20, P12 